\title{
Kesejahteraan psikologis guru honorer di SMA Negeri 13 Depok
}

\author{
Nurul Istiqomah ${ }^{\left.1^{*}\right)}$ \\ Universitas Gunadarma ${ }^{1}$ \\ *) Alamat korespondensi: JI. Raya Outer Ringroad C7 No. 20, Jakarta Barat, 11730, Indonesia; E-mail: \\ nurulbundarumi@gmail.com
}

Article History: Received: 19/06/2021; Revised: 28/06/2021; Accepted: 28/06/2021; Published: 30/06/2021.

How to cite: Istiqomah, N. (2021). Kesejahteraan Psikologis Guru Honorer Di SMA Negeri 13 Depok. Teraputik: Jurnal Bimbingan dan Konseling, 5(1), pp. 48-54. DOI: 10.26539/teraputik.51555

\begin{abstract}
Abstrak: Guru berperan langsung dalam kualitas pembelajaran. Kehidupan guru dengan status honorer jauh dari sejahtera mengingat gaji yang mereka terima jauh di bawah gaji guru yang berstatus PNS. Penelitian ini bermaksud mengetahui bagaimana kesejahteraan psikologis guru yang berstatus honorer di SMAN 13 Depok dan bagaimana upaya guru honorer menghadapi situasi sulit. Metode yang digunakan pada penelitian ini adalah kualitatif dengan jenis penelitian deskriptif. Teknik pengumpulan data melalui wawancara tidak langsung, observasi, dan dokumentasi. Teknik analisis data dengan teknik triangulasi, yang meliputi reduksi data, display data, dan kesimpulan. Hasil penelitian ini yaitu: 1) kesejahteraan psikologis guru honorer di SMAN 13 Depok cukup baik karena sudah terpenuhinya enam komponen kesejahteraan psikologis meskipun dengan berbeda cara. 2) upaya mengahadapi situasi sulit yang dilakukan oleh guru yang berstatus honorer di SMAN 13 Depok yaitu dengan bersabar dan tetap bersyukur menjalani kehidupan sebagai guru honorer.
\end{abstract}

Kata Kunci: Guru Honorer, Kesejahteraan Psikologis

Abstract: Teachers play a direct role in the quality of learning. The life of honorary teachers is far from prosperous because the salaries received are far below the salaries of teachers who are civil servants. This study aims to determine how the psychological well-being of honorary teachers in SMAN 13 Depok and how the efforts of honorary teachers deal with difficult situations. The method used in this research is a qualitative research method with descriptive research type. Data collection techniques through indirect interviews, observation, and documentation. The data analysis technique used triangulation technique, which includes data reduction, data display, and conclusions. The results of this study are: 1) the psychological wellbeing of honorary teachers in SMA Negeri 13 Depok is quite good because the six components of psychological well-being have been fulfilled even though in different ways. 2) the effort to deal with the difficult situation made by honorary teachers at SMA Negeri 13 Depok, namely by being patient and still grateful to live life as an honorary teacher.

Keywords: Honorary Teachers, Psychological Well Being

\section{Pendahuluan}

Penelitian terkait kesejahteraan psikologis (psychological well being) sudah dilakukan sebelumnya oleh Sumule (2008), Setiawan (2014) Deasyanti dan Mafazi (2016), serta Gunawan dan Hendriani (2019). Namun demikian, pada penelitian ini penulis akan membahas tentang psychological well being guru yang berstatus honorer di SMA Negeri 13 Depok.

Ahmadi (2013) mengatakan bahwa manusia yang berkualitas lahir batin terlahir dari pendidikan suatu bangsa yang berkualitas sehingga bangsa tersebut akan maju, damai dan tenteram. Sebaliknya jika pendidikan suatu bangsa mengalami stagnasi dan tidak berkualitas maka bangsa tersebut akan terbelakang di segala bidang.

Nadiem Makarim (2020) sebagai menteri pendidikan saat ini, menyatakan dan percaya bahwa kualitas guru merupakan kunci sukses pembelajaran dan pendidikan. Sayangnya, langkah nyata kebijakan untuk mengatasi masalah utama terkait guru, yaitu kompetensi dan kekurangan guru di beberapa sekolah negeri, belum terdengar sampai saat ini. Berdasarkan prediksi Kementerian Pendidikan dan Kebudayaan (Kemendikbud) sekolah di Indonesia mengalami kekurangan 1 juta guru pada setiap tahun sepanjang kurun 2020-2024. Angka ini ditaksir terus 
meningkat setiap tahun. Mengutip Data Pokok Pendidikan pada 7 Januari 2021, terdapat 3.262.134 guru yang kini mengajar di 435.497 sekolah. Sedangkan jumlah siswa mencapai 52.837.156 orang. Keadaan ini menyebabkan dinas pendidikan daerah melalui kepala sekolah tetap merekrut guru honorer.

Gaji yang diterima guru honorer jauh di bawah gaji guru berstatus PNS. Hal ini menyebabkan kehidupan guru honorer yang terbilang jauh dari sejahtera. Gaji yang diterima guru honorer per bulannya hanya cukup untuk makan-minum per-bulan, dan masih kurang untuk membiayai anak-anaknya melanjutkan pendidikan ke perguruan tinggi (Yamin, 2006). Hal serupa juga dikatakan Setiawan (2014) bahwa untuk memenuhi kebutuhan dasar manusia secara berlanjutan seperti makan, minum, dan sebagainya, manusia dituntut untuk memiliki pekerjaan yang mapan agar dalam memenuhi kebutuhan itu tercukupi.

Konselor memiliki peran dalam mewujudkan sekolah yang damai bagi siswa (Bilqis et al., 2019). Bagaimana guru BK atau konselor bisa optimal, jika kesejahteraan psikologis mereka kurang terpenuhi sebagaimana gaji yang masih sangat jauh dari tingkat kelayakan. Pada suatu penelitian disebutkan betapa pentingnya kesejahteraan ekonomi dalam membangun keharmonisan (Ratnasari \& Bilqis, 2020).

Setiawan (2014) juga mengatakan bahwa konsentrasi guru honorer terpecah menjadi beberapa sisi karena minimnya kesejahteraan mereka. Pada satu sisi seorang guru harus menambah kompetensi akademis pembelajaran dengan terus memperbarui dengan media, metode pembelajaran, dan kapasitas dirinya. Di lain sisi untuk memenuhi kesejahteraannya seorang guru honorer dituntut dengan melakukan usaha atau kegiatan lain seperti bimbingan belajar, wirausaha, dan lain sebagainya. Guru honorer yang mampu menghadapi dan mengatasi masalah serta berkompetisi dengan lingkungan, mengarah pada kondisi psikologis yang positif sehingga terbentuklah psychological well-being dalam dirinya.

Memiliki jiwa yang sejahtera dapat digambarkan dengan seberapa positif seseorang memahami dan menjalankan fungsi-fungsi psikologisnya. Hal ini tentunya didapatkan ketika guru dengan status honorer tidak lagi mempermasalahkan hal yang berhubungan dengan finansial. Kompetensi guru honorer sebagai tenaga pendidik dipertaruhkan ketika dirinya harus dapat mengatur diri dengan baik tanpa mengganggu tugas dalam pengabdian serta pemenuhan kebutuhan hidupnya sehari-hari. Seorang guru yang sejahtera secara psikologis tentunya tidak luput dari pencapaian kebutuhan dalam hidupnya.

Dengan mengkaji kesejahteraan psikologis, manusia akan sadar dan mengetahui tentang bagaimana caranya bersyukur atas setiap nikmat yang diberikan Tuhan. Setiap manusia tentunya mempunyai tanggung jawab yang tidak sama akan dirinya sendiri. Secara tidak langsung manusia akan menyadari betapa besar karunia Tuhan yang telah dianugerahkan kepadanya melalui kondisi-kondisi abnormal pada orang lain. Oleh karena itu, perlu diteliti bagaimana kesejahteraan psikologis guru honorer khususnya di SMA Negeri 13 Depok. Sekolah ini resmi berdiri pada 13 Agustus 2014 dengan jumlah guru PNS sebanyak 13 orang pada saat itu. Setelah enam tahun berdiri SMAN 13 Depok memiliki 20 guru PNS dan 37 guru honorer.

\section{Metode}

Penelitian ini menggunakan pendekatan kualitatif dengan jenis penelitian deskriptif. Maleong (2011) mengatakan bahwa pendekatan kualitatif adalah prosedur penelitian yang menghasilkan data deskriptif berupa kata-kata tertulis, gambar, dan bukan angka, yang mana data diperoleh dari orang-orang dan perilaku yang diamati (Maleong, 2011). Data yang berasal dari catatan lapangan, wawancara, naskah, dokumentasi, dideskripsikan sehingga mampu memberi kejelasan akan keadaan atau realitas.

Sumber data pada penelitian ini terdiri dari sumber data primer dan sekunder. Menurut Sugiyono (2016) sumber data primer merupakan sumber data yang langsung memberikan data kepada pengumpul data (Sugiyono, 2016). Peneliti menggunakan sumber data primer untuk memperoleh data yang tepat dan sesuai, serta memiliki kompetensi sesuai dengan data yang dibutuhkan (purposive). Sumber data primer terdiri dari: 2 orang guru honorer yang mengajar di SMAN 13 Depok sejak pertama sekolah ini berdiri. Mereka diberi inisial R1 (Responden 1) dan 
R2 (Responden 2). Selanjutnya Sugiyono (2016) berpendapat bahwa sumber data sekunder yakni sumber yang tidak langsung memberikan data kepada pengumpul data (Sugiyono, 2016). Sumber data sekunder berupa dokumen dan arsip yang berkaitan dengan kesejahteraan psikologis guru honorer di SMA Negeri 13 Depok.

Teknik pengumpulan data menggunakan wawancara, observasi langsung, dan dokumentasi. Wawancara dilakukan secara tidak langsung melalui aplikasi WhatsApp kepada sumber data primer, yaitu R1 dan R2. Hal ini disebabkan oleh kondisi pandemi yang masih berlangsung saat penelitian ini dilakukan. Wawancara dilakukan untuk mendapatkan informasi tentang psychological well being guru honorer di SMA Negeri 13 Depok. Data yang diperoleh selanjutnya dianalisis menggunakan analisis data kualitatif. Maleong menyatakan analisis data kualitatif digunakan dengan cara bekerja dengan data, mengorganisasi data, memilah data menjadi satuan yang bisa dikelola, mensintesis data, mencari dan menemukan pola, serta menemukan apa yang dapat diceritakan kepada orang lain (Maleong, 2011). Menurut Sugiyono (2016), aktivitas dalam melakukan analisis data, yaitu data reduction, data display, dan conclusion drawing/verification (Sugiyono, 2016). Analisis data dilakukan dengan interaktif dan berlangsung continue sampai tuntas, sehingga datanya sudah jenuh.

\section{Hasil dan Diskusi}

Guru menjalankan berbagai jenis peranan. Berdasarkan UU No. 14 Tahun 2005 tentang Guru dan Dosen dijelaskan bahwa guru adalah pendidik profesional dengan tugas utama mendidik, mengajar, membimbing, mengarahkan, melatih, menilai, dan mengevaluasi peserta didik. Hal ini berkaitan dengan kemampuan dasar yang harus dimiliki seorang guru. Pada pasal 10 ayat (1) menyatakan bahwa kompetensi guru sebagaimana dimaksud dalam Pasal 8 meliputi kompetensi pedagogik, kompetensi kepribadian, kompetensi sosial, dan kompetensi profesional yang diperoleh melalui pendidikan profesi.

Setiap hari para guru berpeluang mempengaruhi kehidupan siswa melalui kepemimpinannya di ruang kelas. Pengaruh positifnya di dalam kelas amat penting untuk menjawab tantangan pendidikan dan memandu pemikiran siswa menuju pengembangan potensi diri mereka sepenuhnya. Hal ini terkait dengan peran guru sebagai pegawai yang berada di instansi pemerintah.

Pemerintah mengenal istilah tenaga honorer dalam melaksanakan suatu tugas pada instansi pemerintah. Termasuk guru sebagai tenaga honorer di sekolah negeri. Kebutuhan akan tenaga honorer pada instansi pemerintah adalah untuk memenuhi kebutuhan pegawai. Perbedaan antara tenaga honorer dengan PNS atau sekarang disebut ASN (Aparatur Sipil Negara) terlihat dalam peraturan perundang-undangan secara implisit. ASN diangkat untuk menduduki jabatan pemerintahan sedangkan tenaga honorer diangkat untuk melaksanakan tugas tertentu.

Sekolah-sekolah negeri masih banyak yang kekurangan guru ASN. Sampai saat ini, kepala sekolah beserta dinas pendidikan daerah tetap merekrut tenaga guru honorer. Hal ini juga terjadi di SMAN 13 Depok. Berikut data jumlah Guru yang bertugas di sekolah tersebut.

Tabel 1. Data Jumlah Guru di SMA Negeri 13 Depok Tahun Pelajaran 2020/2021

\begin{tabular}{lll}
\hline No. & Guru & Jumlah \\
\hline 1 & ASN & 20 \\
\hline 2 & Honorer Provinsi & 28 \\
\hline 3 & Honorer Sekolah & 9 \\
\hline & Total & 57 \\
\hline
\end{tabular}

Dari tabel di atas dapat dilihat jumlah guru dengan status tenaga honorer di SMAN 13 Depok lebih banyak dibandingkan guru ASN. Guru honorer ini ada yang dipekerjakan oleh kepala sekolah sehingga berdampak pada gaji mereka yang kecil. Gaji mereka berasal dari dana bantuan operasional sekolah (BOS), bukan dari APBD karena sekolah negeri tidak boleh 
memungut bayaran dari orangtua siswa. Status dan masa kerja guru honorer beragam. Mulai dari satu tahun sampai lebih dari 10 tahun. Ada guru honorer yang berstatus guru honor sekolah dan guru honor daerah maupun guru honorer yang sudah bersertifikat dan belum bersertifikat (nonsertifikat). Perbedaan status ini membedakan kesejahteraan mereka.

Shah dan Marks menjelaskan bahwa kesejahteraan lebih dari sekedar kebahagiaan serta merasa puas dan bahagia. Kesejahteraan berarti berkembang sebagai pribadi, dipenuhi, dan memberikan kontribusi kepada masyarakat (Dodge, 2012). "Well being is more than just happiness. As well as feeling satisfied and happy, well-being means developing as a person, being fullfilled, and making a contribution to the community."

Sementara itu, menurut Ryff dan Keyes (1995) bahwa tidak adanya rumusan berbasis teori tentang kesejahteraan menjadi membingungkan mengingat banyaknya laporan tentang fungsi positif di subbidang psikologi. "The absence of theory based formulations of well-being is puzzling given abundant accounts of positive functioning in subfields of psychology (Ryff, 1995)". Hal ini menjadikan rancu perumusan kesejahteraan psikologis yang sesungguhnya. Well-being mempunyai cakupan luas yakni subjective well-being (kesejahteraan subjektif) dan psychological well-being (kesejahteraan psikologis). Namun dalam penelitian ini, peneliti menelaah tentang psychological well-being guru honorer SMA Negeri 13 Depok.

Kesejahteraan psikologis adalah sebuah kondisi dimana seseorang mempunyai pandangan positif terhadap dirinya sendiri, sehingga seseorang mampu mencapai kehidupan yang lebih baik (sejahtera) dengan tidak terbebani masa lalu dalam hidupnya. Selain itu, seseorang dianggap sejahtera secara psikologis ketika dia bisa mencapai enam aspek kesejahteraan psikologis seperti yang dirumuskan oleh Ryff yakni penerimaan diri, hubungan positif dengan orang lain, penguasaan lingkungan, kemandirian, tujuan hidup, dan pertumbuhan diri (Ryff, 1995).

\section{Penerimaan Diri (Self Acceptance)}

Penerimaan diri adalah bagaimana seseorang dapat menerima diri apa adanya dan pengalamannya. Definisi penerimaan diri berhubungan dengan rasa percaya diri. Individu mampu menerima dirinya dan masa lalunya baik yang menyenangkan maupun tidak dalam kondisi apapun.

Berdasarkan hasil wawancara dengan responden, keduanya menilai baik diri sendiri dengan memandang diri sebagai pribadi yang mulia serta mempunyai rasa percaya diri yang cukup baik. Kedua responden dapat menerima dirinya dalam kondisi apapun termasuk dalam kondisi mereka sebagai guru honorer di SMA Negeri 13 Depok.

Pengamatan selama bekerja sebagai guru honorer di SMAN 13 Depok, kedua responden menjalankan tugas dengan baik. Tugas utama sebagai guru Bahasa Indonesia dan guru Seni Budaya dilaksanakan R1 dan R2 dengan baik. Keduanya selalu siap dalam mengemban tugas tambahan. R1 sempat menjabat sebagai staff kurikulum dan wali kelas. Sementara R2 yang juga sempat menjabat sebagai wali kelas dan pembina ekstrakurikuler bidang seni juga melaksanakan tugasnya dengan baik. Beberapa kali berhasil membawa nama sekolah mengantarkan siswa menjuarai lomba bidang seni musik.

\section{Hubungan Positif dengan Orang Lain (Positive Relationship With Others)}

Hubungan positif dengan orang lain berarti tingkat kemampuan dalam membangun hubungan dengan orang lain yang hangat dan hubungan interpersonal yang didasari atas kepercayaan, perasaan empati, mencintai, serta kasih sayang.

Kedua guru honorer yang menjadi responden pada penelitian ini mampu membangun hubungan hangat dengan orang lain. Hal ini seperti yang dinyatakan oleh R1 bahwa dirinya dapat berperan aktif dan mengerjakan tugas sesuai dengan tupoksinya. Sementara R2 menyatakan bahwa dirinya berusaha menjadi adaptif agar dapat berhubungan baik dengan orang lain walaupun status mereka sebagai guru honorer.

Berdasarkan hal tersebut di atas dapat dikatakan bahwa baik R1 maupun R2 memiliki kemampuan dalam membina hubungan interpersonal, sehingga hal ini berarti keduanya memiliki perhatian akan kesejahteraan orang lain, dapat menjalin keintiman, berempati, memiliki rasa kasih sayang, dan menghayati konsep giving and receiving dalam sebuah hubungan. 


\section{Penguasaan Lingkungan (Enviromental Mastery)}

Penguasaan lingkungan adalah kemampuan memilih atau menciptakan lingkungan yang sesuai dengan kondisi psikis. Menurut Ryff (1995) individu yang memiliki penguasaan lingkungan yang tinggi mempunyai rasa menguasai, dapat mengatur kegiatan-kegiatan eksternal yang kompleks, menggunakan kesempatan yang ditawarkan di lingkungan secara efektif, berkompetensi dalam mengontrol lingkungan, serta mampu memilih atau menciptakan konteks lingkungan yang sesuai dengan kebutuhan dan nilai pribadinya.

Dalam hal penguasaan lingkungan (enviromental mastery) R1 memilih untuk menjadi dosen tetap, jika kesempatan itu ada, dan meninggalkan profesinya sebagai guru yang berstatus honorer karena menurutnya kesejahteraan di kampus lebih berarti. Demikian pula R2 yang lebih mengejar berkarya dibanding menjadi guru honorer.

Berdasarkan hasil wanwancara tersebut, terlihat bahwa sebagai guru honorer di SMA Negeri 13 Depok, kedua responden tersebut mampu untuk memilih lingkungan dan menggunakan kesempatan sesuai kondisi psikis mereka. Apalagi jika lingkungan tersebut selaras dengan kebutuhan serta nilai pribadinya.

\section{Kemandirian (Autonomy)}

Kemandirian adalah tingkat kemampuan seseorang dalam menentukan nasib, kebebasan, pengendalian dan pengaturan perilaku internal individual. Hal ini menjadi dasar kepercayaan bahwa pikiran dan tindakan individu berasal dari dirinya sendiri, tanpa adanya kendali dari orang lain. Orang yang memiliki kemandirian dapat mengontrol dirinya sendiri serta mempunyai keinginan sesuai standar individu tersebut sehingga mampu membentuk kepercayaan pada diri sendiri, bukan kepercayaan pada orang lain.

Sebagai guru honorer, baik R1 maupun R2 mampu mengatur dirinya sendiri tanpa dikendalikan oleh orang lain. R1 menunjukkan kemandirian melalui pernyataannya "Saya selalu mempunyai rencana yang akan dilakukan dan berusaha agar rencana tersebut bisa tercapai. Saya juga membuat jadwal sendiri agar tidak terjadi bentrok sehingga saya mampu memanage waktu".. Sementara R2 menunjukkan kemandiriannya dengan menetapkan skala prioritas sesuai hak dan kebutuhan. Baginya waktu bisa diatur secara fleksibel dengan cara jujur.

Berdasarkan hasil wawancara kepada R1 dan R2 dapat dikatakan bahwa keduanya telah memiliki kemandirian pada diri masing-masing. Mereka dapat mengatur diri tanpa adanya kendali orang lain.

\section{Tujuan Hidup (Purpose in Life)}

Individu yang positif merasa bahwa hidupnya berarti. Mereka memiliki tujuan dan arah hidup. Sebaliknya, individu yang kurang memiliki tujuan hidup, mereka kurang memiliki arah kehidupan yang jelas, hanya memiliki sedikit keinginan, tidak memandang pengalaman masa lalu, serta tidak mempunyai bakat yang menjadikan hidupnya lebih berarti.

Sebagai guru honorer yang mengajar sudah cukup lama di SMA Negeri 13 Depok, R1 dan R2 masih memiliki cita-cita dan tujuan hidup agar bisa diangkat menjadi ASN. Dengan terus belajar, berusaha, dan berdoa, $\mathrm{R} 1$ berharap suatu saat nanti dirinya akan diangkat menjadi dosen/guru ASN. Sementara R2 terus berusaha dengan membuka koneksi dan wawasan demi kebutuhan dirinya. Kedua responden ini tetap berharap dapat menjadi ASN apalagi jika mengamati PP No. 49 Tahun 2018 tentang Manajemen PPPK (Pegawai Pemerintah dengan Perjanjian Kerja). Perjanjian kerja PPPK minimal satu tahun serta bisa diperpanjang sesuai dengan kebutuhan.

Meskipun ada banyak guru honorer yang bisa memenuhi kebutuhan hidupnya dengan mengandalkan pekerjaan sampingan, yakni mengajar di tempat lain, bisnis, ataupun yang lainnya, guru honorer tetap merasa kurang puas ketika belum menjadi guru tetap atau ASN, seolah ada tujuan hidup yang belum tercapai. Manusia tidak pernah bisa mencapai kata puas dalam mendapatkan sesuatu. Oleh karena itu setiap manusia mempunyai takaran yang tidak sama dalam menjelaskan tentang kesejahteraan psikologis. 


\section{Pertumbuhan diri (Personal Growth)}

Pertumbuhan pribadi adalah tingkat kemampuan individu dalam mengembangkan potensinya secara berkelanjutan serta menumbuhkan dan memperluas diri sebagai manusia. Kemampuan ini adalah gagasan dari individu untuk terus memperkuat kondisi internal alamiahnya.

Jika dilihat dari komponen pertumbuhan diri (personal growth), kedua responden mampu mengembangkan potensinya dan memperluas diri secara terus-menerus sebagai manusia. Hal ini seperti yang dikatakan R1 bahwa dirinya suka mengikuti pelatihan atau seminar-seminar untuk mengembangkan potensi dirinya. Begitu juga dengan R2 yang terus mencoba hal-hal baru.

Berdasarkan hasil dan pembahasan enam komponen kesejahteraan psikologis di atas, selama enam tahun menjadi guru honorer, kedua responden memiliki tingkat kesejahteraan psikologis yang cukup baik. Enam komponen kesejahteraan psikologis terpenuhi dengan baik. Di samping itu, kedua responden memiliki potensi yang dikembangkan di bidang lain selain menjadi guru honorer. Selain sebagai guru honorer R1 juga berprofesi sebagai dosen kontrak pada sebuah PTS di Jakarta. Sementara R2 yang seorang guru honorer pelajaran seni budaya berprofesi sebagai musisi. Hal tersebut dilakukan oleh kedua responden sebagai upaya untuk menghadapi situasi sulit. Sehingga mereka mampu bertahan dengan upah yang diterima sebagai guru dengan status honorer di SMA Negeri 13 Depok.

Upaya lain yang dilakukan oleh R1 dalam menghadapi situasi sulit, yaitu dengan bersabar menghadapi kehidupan sebagai guru honorer dan bisa belajar mengatur keuangan di saat rapelan terjadi, serta berkonsultasi ketika menghadapi masalah yang tidak dapat ditangani sendiri, sementara R2 tetap bersyukur dan lebih memilih untuk mengamati masalah tersebut, berfikir, serta mencari solusinya sendiri. Hal ini menunjukkan bahwa setiap manusia memiliki kemampuan yang berbeda dalam upaya untuk menghadapi situasi sulit. R1 dengan R2 melakukan upaya sesuai dengan kapasitas mereka.

\section{Simpulan}

Kesejahteraan psikologis adalah kondisi di mana seseorang mempunyai pandangan positif terhadap dirinya sendiri, sehingga mampu mencapai kehidupan yang lebih baik (sejahtera) dengan tidak terbebani pengalaman masa lalu dalam hidupnya.

Dari data penelitian yang diperoleh, kedua subjek dapat dikatakan memiliki kesejahteraan psikologis yang cukup baik. Hal ini terlihat dari terpenuhinya enam komponen kesejahteraan psikologis meskipun berbeda cara. Upaya kedua subjek dalam menghadapi situasi sulit dan mencapai kesejahteraan psikologis dapat digambarkan dengan adanya usaha dari kedua subjek untuk memenuhi kebutuhannya sehari-hari dengan tidak mengganggu pekerjaannya sebagai guru honorer. Kedua subjek memilih kegiatan yang linier dengan bidangnya masing-masing. R1 sebagai guru honorer sekaligus dosen sementara R2 sebagai guru honorer sekaligus musisi.

Penelitian ini hanya berfokus pada kesejahteraan psikologis guru honorer. Tentunya banyak aspek yang mempengaruhi kesejahteraan psikologis guru honorer yang dapat dijadikan penelitian lanjutan.

\section{Ucapan Terima Kasih}

Ucapan terima kasih diberikan kepada dosen pembimbing yang senantiasa sabar dalam membimbing, sehingga terwujudnya artikel ini. 


\section{Daftar Rujukan}

Ahmadi. (2013). Manajemen Kurikulum : Pendidikan Kecakapan Hidup. Yogyakarta : Pustaka Ifada.

Bilqis, F., Karina, T., \& Latipah, I. C. (2019). Peran konselor dalam mewujudkan sekolah aman dan damai bagi siswa. TERAPUTIK: Jurnal Bimbingan Dan Konseling, 2(3), 115-122.

CNN Indonesia. (6 Oktober 2020). Kemendikbud : Sekolah Kekurangan 1 Juta Guru Hingga 2024. Diunduh dari https://www.cnnindonesia.com/nasional/20201005180513-20554645/kemendikbud-sekolah-kekurangan-1-juta-guru-hingga-2024. Diakses 3 Januari 2021.

Deasyanti dan Mafazi, Amalina. (2016). Efikasi dan Kesejahteraan Psikologis pada Guru SMP, "Jurnal Penelitian dan Pengukuran Psikologi", Vol. 5 No.2.

Dodge, R., Daly, A., Huyton, J., \& Sanders, L. (2012). The Challenge Of Defining Wellbeing. International Journal of Wellbeing, 2(3), 222-235. doi:10.5502/ijw.v2i3.4 .

Gunawan, Lalu Reza, dan Hendriani, Wiwin. (2019). Psychological Well-being pada Guru Honorer di Indonesia : A Literature Review, "Jurnal Psikologi : Psikoislamedia", Vol.4 No.1.

Maleong, Lexy J. (2011). Metode Penelitian Kualitatif, Bandung : Remaja Rosda Karya.

Media Indonesia. (3 Februari 2020). Mengatasi Kekurangan Guru. Diunduh dari https://mediaindonesia.com/opini/287392/mengatasi-kekurangan-guru diakses 3 Januari 2021.

Ratnasari, D., \& Bilqis, F. (2020). Layanan informasi untuk membangun keharmonisan keluarga pada orangtua atau wali asuh di Yayasan Jakarta Selatan. Teraputik: Jurnal Bimbingan Dan Konseling, 4(1), 35-42.

Ryan, R., M., dan Deci, E. L. (2001). On Happiness And Human Potentials : A Review of Research on Hedonic and Eudaimonic Well Being: Annual Review Psychology.

Ryff dan Keyes. (1995). The Structure of Psychological Well-Being Revisited. Journal of Personality and Social Psychology. Vol. 69 No.4 719-727.

Setiawan, Heri. (2014). Psychological Well-Being Pada Guru Honorer Sekolah Dasar Di Kecamatan Wonotunggul Kabupaten Batang. Skripsi. Semarang Jurusan Psikologi, Fakultas IImu Pendidikan Universitas Negeri Semarang.

Sugiyono. (2016). Metode Penelitian Pendidikan, Bandung: Alfabeta,

Sumule, R. P. (2008). Psycological Well Being pada Guru yang Bekerja di Yayasan PESAT Nabire, Papua. Skripsi. Depok. Fakultas Psikologi. Universitas Gunadarma.

Undang-undang No. 14 Tahun 2005 Tentang Guru dan Dosen.

Undang-undang No. 5 Tahun 2014 Tentang Aparatur Sipil Negara (ASN).

Yamin, Martinis. (2006). Sertifikasi Profesi Keguruan Di Indonesia. Jakarta : Gaung Persada Press.

\section{Competing interests:}

The authors declare that they have no significant competing financial, professional or personal interests that might have influenced the performance or presentation of the work described in this manuscript. 